\title{
Актуальні питання в проблемі нейрокогнітивних порушень
}

\author{
Л.А. Дзяк \\ Державний заклад «Дніпровський державний медичний університет», Дніпро, Україна
}

Сьогодні проблема нейрокогнітивних розладів (НКР) викликає значний інтерес у неврологів, психіатрів та лікарів інших спеціальностей. Це обумовлено збільшенням кількості пацієнтів із когнітивними розладами, їх негативним впливом на якість життя самих пацієнтів та їх родичів, що лягає значним тягарем на суспільство в цілому. Саме порушення когнітивних функцій $\epsilon$ головною причиною інвалідизації населення. За результатами крупномасштабного дослідження, саме психоневрологічні розлади посідають 1-ше місце серед інших причин у осіб з інвалідністю (рис. 1) [1].

Рисунок 1 Порушення когнітивних функцій - одна з провідних причин інвалідизації населення

\begin{tabular}{|c|c|c|}
\hline & $\begin{array}{c}\text { Психічні } \\
\text { та поведінкові } \\
\text { розлади }\end{array}$ & $\begin{array}{c}\text { Неврологічні } \\
\text { розлади }\end{array}$ \\
\hline Нейропсихіатричні захворювання & 22,7 & $5,5 \quad 28,2$ \\
\hline М'язово-скелетні захворювання & 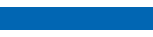 & 21,3 \\
\hline Інші незаразні хвороби & 11,2 & \\
\hline $\begin{array}{l}\text { Цукровий діабет та інші ендокринні захворювання, } \\
\text { урогенітальні захворювання, хвороби системи крові }\end{array}$ & 7,3 & \\
\hline Дефіцит харчування & 6,4 & \\
\hline Хронічні респіраторні захворювання & 6,3 & \\
\hline $\begin{array}{r}\text { Ненавмисні травми } \\
\text { (крім дорожньо-транспортних травм) }\end{array}$ & 3,4 & \\
\hline Занедбані тропічні хвороби та малярія & 2,9 & \\
\hline Кардіоваскулярні та циркуляторні хвороби & 2,8 & \\
\hline $\begin{array}{r}\text { Дiарея, респіраторні інфекції нижніх дихальних шляхів, } \\
\text { менінгіт та інші поширені інфекційні захворювання }\end{array}$ & 2,6 & \\
\hline 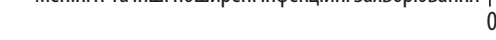 & 10 & $25 \quad 30$ \\
\hline
\end{tabular}

Когнітивна недостатність розвивається при самих різних за етіологією захворюваннях, не тільки неврологічних. Вона може виникати при різних токсичних ураженнях. Головний мозок $\epsilon$ органом-мішенню при багатьох соматичних захворюваннях, що впливає на показники поширеності і, безумовно, потребує ранньої діагностики цієї патології. Площа кори головного мозку, що забезпечує когнітивні функції, значно перевищує площу первинних моторних і сенсорних коркових полів. У зв'язку 3 цим когнітивні розлади $\epsilon$ одним із найпоширеніших симптомів у клінічній практиці.

Останніми роками відбулася суттєва ревізія поглядів на патогенез формування когнітивних порушень і вибір пріоритетних напрямів терапії. Суттєвих змін зазнали уявлення про найважливіші клінічні прояви когнітивних порушень, що відображають порушення інтегративної діяльності головного мозку. Перш за все це стосується визначення когнітивних розладів. Згідно з останнім переглядом міжнародних рекомендацій з діагностики психічних розладів (Diagnostic and Statistical Manual of Mental Disorders - DSM-V) до когнітивних розладів відносять зниження порівняно з преморбідним рівнем однієї або декількох вищих мозкових функцій, що забезпечують процеси сприйняття, збереження, перетворення та передачі інформації [2]. Термін «нейрокогнітивні розлади» означає групу станів, яка співвідноситься з розділом DSM-IV «Деменція, делірій, амнестичний та інші когнітивні розлади» і включає делірій і синдроми великого і малого НКР $з$ їх етіологічними підтипами (табл. 1), тобто тими захворюваннями, на фоні яких розвиваються нейрокогнітивні порушення. Це перш за все первинні нейродегенеративні захворювання, нейроінфекції та демієлінізуючі захворювання нервової системи, серцево-судинні захворювання і захворювання головного мозку, дисметаболічні розлади, черепно-мозкова травма, пухлини головного мозку, розлади ліквородинаміки (рис. 2).

Таблиця 1 Нейрокогнітивні розлади (НКР)

\begin{tabular}{ll}
\hline \multicolumn{1}{c}{ Нейрокогнітивні порушення } \\
\hline DSM-IV (1994) & $\leftrightarrow$ DSM-V (2013) \\
\hline Легкі/помірні когнітивні порушення & Малий HKP \\
\hline Деменція & Великий НKP \\
\hline & Делірій \\
\hline
\end{tabular}

Рисунок 2 Захворювання, при яких розвиваються нейрокогнітивні порушення

\begin{tabular}{|c|c|c|c|}
\hline $\begin{array}{c}\text { Нейродегенератив- } \\
\text { ні захворювання }\end{array}$ & $\begin{array}{c}\text { Серцево-судинні } \\
\text { захворювання } \\
\text { і захворювання } \\
\text { головного мозку }\end{array}$ & $\begin{array}{c}\text { Змішані } \\
\text { судинно-дегенера- } \\
\text { тивні захворювання }\end{array}$ & $\begin{array}{c}\text { Дисметаболічні } \\
\text { розлади }\end{array}$ \\
\hline 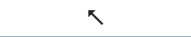 & $\uparrow$ & $\uparrow$ & $\nearrow$ \\
\hline \multicolumn{4}{|c|}{ Захворювання, при яких розвиваються нейрокогнітивні порушення } \\
\hline$\swarrow$ & $\downarrow$ & $\downarrow$ & $\searrow$ \\
\hline $\begin{array}{c}\text { Нейроінфекції } \\
\text { і демієлінізуючі } \\
\text { захворювання } \\
\text { нервової системи }\end{array}$ & $\begin{array}{c}\text { Черепно-мозкова } \\
\text { травма } \\
\text { та її наслідки }\end{array}$ & $\begin{array}{c}\text { Пухлини головного } \\
\text { мозку }\end{array}$ & $\begin{array}{c}\text { Розлади } \\
\text { ліквородинаміки, } \\
\text { в тому числі } \\
\text { нормотензивна } \\
\text { гідроцефалія }\end{array}$ \\
\hline
\end{tabular}

Говорячи про підтипи великого і малого НКР, слід враховувати, що саме ці підтипи повинні бути внесені при встановленні клінічного діагнозу, що необхідно для визначення правильного лікування пацієнта. Підтипами великого і малого НКР $\epsilon$ судинний НКР, а також НКР, викликаний хворобою Альцгеймера, хворобою дифузних тілець Леві, хворобою Паркінсона, фронтотемпоральною деменцією, травматичним ураженням головного мозку, ВІЛінфекцією, дією лікарських або наркотичних речовин, хворобою Гентінгтона, пріонним захворюванням, іншими захворюваннями, НКР внаслідок дії декількох причин, неуточнений НКР.

Слід пам'ятати, що, незважаючи на те, що когнітивні порушення відмічають при багатьох захворюваннях, до групи НКР включають лише ті розлади, при яких когнітивний дефіцит $є$ основним набутим симптомом, не пов'язаним із порушеннями розвитку, тобто не виникає з моменту народження або перших років життя.

Діагностичні критерії великого і малого НКР представлені у табл. 2. Головним діагностичним критерієм $\epsilon$ оцінка когнітивного зниження, яке може бути в одному або декількох доменах когнітивних функцій. При помірних когнітивних порушеннях має місце малий, при виражених - великий НКР. Безумовно, ці когнітивні розлади повинні бути підтверджені нейропсихологічним тестуванням. Близькі родичі та лікуючий лікар повинні відмічати помірне або виражене зниження когнітивних функцій у пацієнта. Головним діагностичним тестом $\epsilon$ оцінка незалежності пацієнта. Так, при легкому НКР когнітивний дефіцит не знижує незалежність 
Таблиця 2 Діагностичні критерії великого і малого HKP (DSM-V)

\section{Великий НКР}

А. Наявність вираженого когнітивного зниження порівняно з вихідним рівнем в $\geq 1$ домені когнітивних функцій (увага, виконавчі функції, навчання і пам'ять, мова, перцептуальномоторні здібності або соціальне впізнавання) на таких підставах:

1. Пацієнт, обізнані близькі або лікуючий лікар пацієнта відзначають істотне зниження когнітивних функцій та

2. Виявляють виражені порушення когнітивних функцій, переважно підтверджені при стандартизованому нейропсихологічному тестуванні або, при його відсутності, в процесі іншої кількісної клінічної оцінки.

В. Когнітивний дефіцит знижує незалежність у побуті (тобто як мінімум потрібна допомога у складних продуктивних повсякденних діях, наприклад при оплаті рахунків або контролі прийому ліків)

С. Когнітивний дефіцит не може бути пов'язаний виключно із розвитком делірію.

D. Когнітивний дефіцит не пов'язаний з наявністю у пацієнта інших захворювань (наприклад великої депресії або шизофренії).

пацієнта у виконанні повсякденних справ. При значному зниженні незалежності пацієнта у побуті та професійній діяльності слід підозрювати великий НКР і вживати відповідних заходів.

У міжнародних рекомендаціях DSM-V замість звичного терміну «деменція» використовується термін «виражений» (англ. major - великий) НКР. Проте поняття «деменція» продовжує використовуватися при позначенні патогенетичних підтипів, де цей термін $є$ стандартним. Тому у класифікації підтипів існує деменція (васкулярна та ін.).

Деменція - одне з найактуальніших питань сучасної клінічної практики. Станом на 2020 р. кількість осіб із встановленим діагнозом «деменція» досягло 47 млн в усьому світі i, за прогнозами Всесвітньої організації охорони здоров'я, відмічатиметься прогресуюче збільшення кількості цих пацієнтів (рис. 3). Необхідно пам'ятати, що, поряд з підвищенням цих показників можливості ефективної терапії все ще обмежені. Також обмежена діагностика на самих ранніх етапах розвитку цього стану, а також в оцінці факторів ризику, які призводять до НКР, що досягає ступеня деменції.

Рисунок 3 Глобальний тягар деменції: світові тенденції

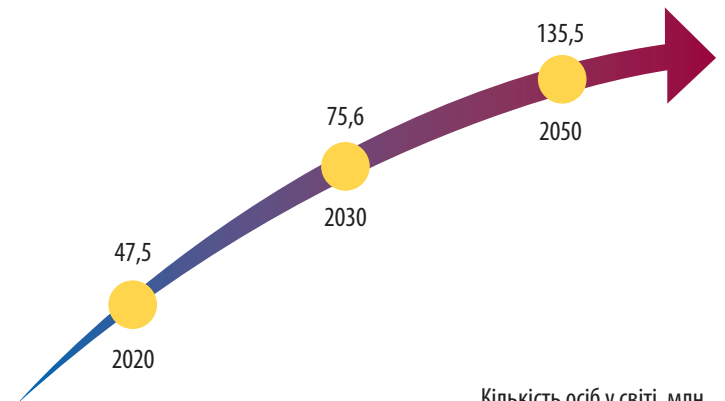

Кількість осіб у світі, млн

Основним фактором ризику розвитку деменції $\epsilon$ вік - цей факт доведений в усіх дослідженнях. Старіння населення - глобальний світовий феномен. 3 кожним роком збільшується кількість осіб, які належать до старшої вікової групи, зростає розповсюдженість психічних розладів у цієї категорії населення. Когнітивні порушення займають 1-ше місце в старших вікових групах і на сьогодні становлять близько 17\%. Цікаві дані отримано у багатоцентровому дослідженні EURODEM, що поєднало зусилля усіх великих колективів Західної Європи, в якому показано сходинкоподібне збільшення поширеності деменції з віком пацієнтів. Так, з 65-69-річного віку кожні 5 років частка осіб із деменцією збільшувалася майже удвічі. Значущих статевих відмінностей не виявлено. У віці <75 років серед пацієнтів із деменцією вища частка жінок, $>75$ років - чоловіків. Ці тенденції відмічали в усіх 12 дослідженнях, результати яких використовували для аналізу [3].

Хвороба Альцгеймера - хронічне захворювання нервової системи, яке вперше описано Алоїзом Альцгеймером (Alois Alzheimer) у 1906 р. Хворобу Альцгеймера в усьому світі відмічають у 44 млн осіб. Діагностика захворювання досить складна і потребує підвищеної уваги: вважається, що діагностований лише 1 із 4 випадків хвороби. У 2 із 3 випадків хвороба Альцгеймера розвивається у жінок. Хвороба Альцгеймера і деменція найбільш поширені у країнах Західної Європи, незважаючи на те, що цим пацієнтам там приділяють досить багато уваги. У США також відмічається неухильне зростання кількості випадків хвороби Альцгеймера. Тривалість життя після встановлення діагнозу становить 4-8 років. Глобальний фінансовий тягар хвороби Альцгеймера і деменції - 65 млрд дол. США, що еквівалентно 1\% ВВП.

Деменція не $\epsilon$ нормальним процесом старіння. Слід зазначити, що для встановлення діагнозу клінічна картина захворювання має відзначатися не менше ніж пів року. Також можливий більш прогресивний початок хвороби. Погіршення пам'яті найпоширеніший симптом хвороби Альцгеймера. Рекомендовано звернутися до лікаря або у спеціалізовані організації у разі наявності $\geq 1$ із наступних ознак:

1. Людина має проблеми з пам'яттю.

2. Погіршилась здатність справлятися зі справами, які раніше вдавалися.

3. Людина має проблеми з мовою.

4. $€$ втрата у часі та просторі.

5. Людина звинувачує близьких у крадіжці.

6. Перепитує одне і те саме багато разів.

7. Кладе речі у нехарактерні місця.

8. Плутається між об'єктами і предметами.

9. Відчуває часті зміни настрою.

10. Впадає в депресію, апатію, втрачає інтерес до життя.

Сьогодні старіння і головний мозок - проблема, якою займаються всі фахівці. Відомо, що втрата нейрональних утворень (гіпотрофія лобових часток, гіпокампу, стоншання верхнього шару кори) клінічно виражається розвитком нейропсихіатричних синдромів. Встановлена навіть залежність маси головного мозку від віку. Проте проведено дослідження серед довгожителів, в яких дійсно виявлені зміни на магнітно-резонансній томограмі головного мозку, але при цьому в них відмічені нормальні когнітивні функції. 3'явилася нова категорія хворих - «суперстарики» (англ. - SuperAgers), в яких процес «скорочення» головного мозку відбувається повільніше, ніж у їх однолітків, і не супроводжується розвитком когнітивних порушень. Безумовно, це дуже соціально активні люди, які дотримуються правил здорового харчування, мають повноцінний сон, регулярне фізичне навантаження, контролюють стрес, займаються стимулюючими видами інтелектуальної діяльності. Наявність цієї категорії людей змушує думати про те, чи тільки зменшення маси головного мозку призводить до розвитку когнітивних порушень, пов'язаних із віком. Доведено, що одним із факторів, що визначають ступінь когнітивного потенціалу, $\epsilon$ нейропластичність головного мозку - здатність різних відділів центральної нервової системи до реорганізації за рахунок структурних змін у речовині головного мозку, тобто здатності клітинних елементів змінювати свої функції, хімічний профіль (кількість і типи нейротранс- 
мітерів, що продукуються) або структуру. У нейропластичних процесах беруть участь усі елементи нейроваскулярної одиниці (нейрони, глія, судинна система), змінюються функціональна активність синапсів, їх кількість, відбувається формування нових зв'язків і функціональних систем. При нормальному старінні синаптична щільність досить висока, а при деменції щільність синапса і власне функціональна активність порушуються.

у той самий час вікові когнітивні зміни, що не досягають ступеня деменції, проявляються у порушенні епізодичної пам'яті, швидкості обробки інформації, виконавчих функцій/ уваги. Вікові когнітивні зміни можуть бути пов'язані з уповільненням обробки, нездатністю ігнорувати непотрібну інформацію і меншим використанням стратегій, що сприяють навчанню і запам'ятовуванню. Декларативна (експліцитна) пам'ять погіршується в ході нормального старіння (епізодична - погіршення протягом всього життя, семантична — погіршення на пізніх етапах життя). Недекларативна (імпліцитна) пам'ять не змінюється. Швидкість накопичення інформації і витяг її з пам'яті знижується, в той час як раніше накопичена інформація зберігається [4].

Слід зазначити, що велику роль у розвитку когнітивних порушень в осіб похилого, а також молодого віку, відіграє зниження слуху. У дослідженнях показано, що у $40-50 \%$ осіб віком $\geq 65$ років відмічають порушення слуху, що достатньо чітко верифіковано, а у віці $>70$ років цей показник досягає вже $83 \%$. Зниження слуху, або розвиток нейросенсорної туговухості, - 3-й за поширеністю хронічний стан в осіб похилого віку.

Виявлена невелика, але статистично значуща кореляція між гостротою слуху і когнітивними функціями інтелектуально збережених осіб похилого віку, а також наявністю деменції $[5,6]$. Кореляція зберігалася навіть після поправок на стать, вік, освіту, наявність цукрового діабету, артеріальної гіпертензії, тютюнопаління. Периферичне зниження слуху незалежно пов'язане з прискореною атрофією головного мозку як загалом, так і окремих його ділянок, особливо правої тім'яної частки. Розвиваються не тільки нейросенсорна туговухість, але й запаморочення та інші ознаки дисфункції вестибулярного апарату. Зв'язок між сенсорними і когнітивними порушеннями показаний у популяційних багаторічних дослідженнях Maastricht aging study та Australian Longitudinal Study of Ageing [7, 8]. Встановлений сильний зв'язок між гостротою сприйняття в слуховій і зоровій ділянках і когнітивними функціями, включаючи пам'ять.

Деменція - це не лише порушення пам'яті. В останні роки проведені дуже цікаві дослідження, в яких показано, що саме депресія, яка розвивається в осіб не лише похилого, але й молодого віку, $\epsilon$ продромальним синдромом розвитку деменції. Виявлено, що поступове прогресування депресивних симптомів, на відміну від більш стійких симптомів, асоційовано з підвищеним ризиком розвитку деменції. У популяційному дослідженні Rotterdam Study взяли участь дорослі особи віком $\geq 55$ років, період спостереження становив 1993-2004 pp. Увага дослідників була зосереджена на пацієнтах, які з самого початку не мали деменції. У 3325 осіб (середній вік 74,8 року, $60 \%$ - жінки) виявлені депресивні симптоми різного ступеня вираженості. Симптоми депресії оцінювали за валідизованою голландською шкалою CES-D та шкалою тривожності і депресії Hospital Anxiety and Depression Scale. У результаті виокремлено 5 моделей розвитку депресивних симптомів: 1-ша характеризувалася низькою вихідною сумою балів за шкалою CES-D (73\% пацієнтів), 2-га - помірно високою стартовою сумою балів і наступним ії зниженням (11\% пацієнтів), 3-тя - початково низькою сумою балів, наступним її зростанням і зниженням у подальшому (5\% пацієнтів), 4-та - низькою вихідною сумою балів і потім стійким її підвищенням (8\% пацієнтів), 5-та - початково високою сумою балів (3\% пацієнтів). У 434 учасників діагностовано деменцію. 3 високим ризиком розвитку деменції була асоційована модель з прогресивним підвищенням тяжкості симптомів депресії (відношення ризиків (Hazard ratio) 1,42; 95\% довірчий інтервал (ДІ) 1,05-1,94; $\mathrm{p}=0,024)$. При цьому саме така модель симптомів депресії пов'язана з підвищеним ризиком розвитку деменції після нівелювання інсульту (відношен- ня ризиків 1,58; 95\% ДІ 1,15-2,16; $\mathrm{p}=0,0041)$. Високий ризик деменції відмічений в осіб з прогресивно наростаючою тяжкістю симптомів, що може характеризувати депресію як продромальний симптом деменції [9].

У нещодавно опублікованому дослідженні показано, що декілька нейропсихологічних станів призводять до розвитку деменції. Дослідники з США проаналізували 1500 пацієнтів із хворобою Альцгеймера, у 43,3\% з яких відмічали депресію, $32,3 \%$ - тривожні розлади, $1,2 \%$ - біполярний розлад, $1 \%-$ посттравматичний стресовий розлад і $1 \%$ - шизофренію. Показано, що у пацієнтів із депресією дебют хвороби Альцгеймера наставав на 2,1, у пацієнтів з тривожними розладами - на 3,3, за наявності $\geq 3$ захворювань — на 7,3 року раніше, ніж у осіб без цього захворювання ( $<<0,001)$. При цьому група з двома психіатричними захворюваннями включала депресію і тривожний розлад. У випадку одночасної наявності 3 захворювань у більшості випадків йшла мова про депресію, тривожний розлад і посттравматичний стресовий розлад. У якості можливих чинників, що зумовлюють їх розвиток, дослідники виділили чоловічу стать, аутоімунні захворювання - цукровий діабет 1-го типу, розсіяний склероз, судоми (нейрозапалення може робити внесок у зв'язок між депресією і раннім дебютом хвороби Альцгеймера, у паці$\epsilon$ нтів з тривожними розладами виявлено більш високу частоту судом) [10].

Встановлено, що на фоні депресивних розладів порушуються процеси нейропластичності, зокрема зменшується число контактів між нервовими клітинами, змінюється швидкість передачі імпульсу, зменшується кількість нейронів. Крім того, на фоні депресії відмічають зменшення об'єму гіпокампа і префронтальної кори. Подібні зміни викликають порушення нормального функціонального зв'язку між зазначеними структурами.

За даними Канадського дослідження за участю близько 2000 пацієнтів із нейропсихологічними порушеннями (тривога, депресія, порушення сну), застосування бензодіазепінів протягом >180 днів супроводжувалося 1,5-кратним підвищенням ризику розвитку хвороби Альцгеймера. Ризик знаходився у залежності від тривалості прийому препаратів і був вищим для препаратів з більшим періодом напіввиведення [11]. Також отримано нові дані щодо підвищення ризику розвитку хвороби Альцгеймера на фоні прийому бензодіазепінів. У національне дослідження випадок - контроль увійшли всі особи, що мешкають у домашніх умовах, яким встановлено клінічний діагноз «хвороба Альцгеймера» в період 2005-2011 рр. (n=70 719). Групу контролю становили особи без хвороби Альцгеймера ( $\mathrm{n}=282$ 862). В усіх учасників аналізу оцінювали призначення бензодіазепінів з 1995 р. Результати свідчать, що застосування бензодіазепінів асоційовано з помірним підвищенням ризику хвороби Альцгеймера (скориговане відношення ризиків 1,06; 95\% ДІ 1,04-1,08). Звертав увагу дозозалежний ефект, що підвищував ризик розвитку захворювання у 5,7 раза. Достовірних відмінностей у частоті захворювання на фоні різних груп бензодіазепінів (тривалої дії або препаратів з невеликою і середньою тривалістю дії) не отримано [12].

Суттєвими факторами ризику розвитку деменції, безумовно, $\epsilon$ судинні захворювання. Особливо важливим $\epsilon$ профіль судинної коморбідності (табл. 3). Згідно з результатами міжнародних епідеміологічних досліджень, судинна етіологія - 3-тя за поширеністю (після хвороби Альцгеймера і дегенеративного процесу з тільцями Леві) причина деменції у похилому $\mathrm{i}$ старечому віці. На сьогодні найбільш прогностично значущий фактор ризику розвитку деменції - артеріальна гіпертензія, що показано в багатьох дослідженнях. Виявлено, що гіпоперфузія головного мозку пов'язана з підвищенням ризику розвитку деменції (стандартизоване відношення ризиків 1,31; 95\% ДІ 1,07-1,61 при зниженні перфузії на 1 SD), причому обсяг зниження мозкового кровотоку відмічено в усіх ділянках головного мозку [14]. При цьому порушується проникність гематоенцефалічного бар'єру, у головний мозок із сироватки крові потрапляють нейротоксичні і васкулотоксичні білки і макромолекули, що призводить до вторинної нейродегенерації і втрати білої речовини $[15,16]$. Останнім часом досить широко 
обговорюється лімфатична система, що підтримує рідинний баланс та очищення головного мозку. Важливу роль відіграє атеросклеротичне ураження судин головного мозку. Показано, що процес поширюється на дистальні відділи артеріальної системи і відбувається вторинна перебудова судин мікроциркуляторного русла. Клінічні прояви хронічного порушення мозкового кровообігу, що відображають ангіоенцефалопатію, розвиваються, коли процес локалізується переважно на рівні мікроциркуляторного русла і в дрібних перфоруючих артеріях, які кровопостачають саме ті структури головного мозку, які беруть участь у формуванні інтегративних функцій.

Таблиця 3 Профіль судинної коморбідності в осіб віком $\geq 65$ років [13]

\section{Найчастіші поєднання за наявності двох та трьох серцево-судинних} захворювань/станів у пацієнтів віком $\geq 65$ років

\begin{tabular}{|c|c|}
\hline Два захворювання/стани & Частота, \% \\
\hline Артеріальна гіпертензія + гіперліпідемія & 57,2 \\
\hline Артеріальна гіпертензія + ішемічна хвороба серця & 36,8 \\
\hline Артеріальна гіпертензія + цукровий діабет & 32,7 \\
\hline Ішемічна хвороба серця + гіперліпідемія & 31,3 \\
\hline \multicolumn{2}{|c|}{ Три захворювання/стани } \\
\hline
\end{tabular}

\begin{tabular}{ll}
\hline Артеріальна гіпертензія + ішемічна хвороба серця + гіперліпідемія & 35,8 \\
\hline Артеріальна гіпертензія + гіперліпідемія + цукровий діабет & 31,7 \\
\hline Артеріальна гіпертензія + цукровий діабет + ішемічна хвороба серця & 21,5
\end{tabular}

Прогресування когнітивних порушень відмічається у паці$\epsilon$ тів із хронічною серцевою недостатністю зі зниженою фракцією викиду лівого шлуночка. Зниження серцевого викиду внаслідок порушення скоротливої функції серця викликає погіршення церебрального кровотоку, сприяючи формуванню або обваженню проявів хронічної ішемії головного мозку. Як показано на рис. 4, у 65,7\% хворих із серцевою недостатністю зі зниженою фракцією викиду відмічаються переддементні когнітивні порушення.

Рисунок 4 Прогресування когнітивних порушень у пацієнтів із хронічною серцевою недостатністю зі зниженою фракцією викиду лівого шлуночка [17]

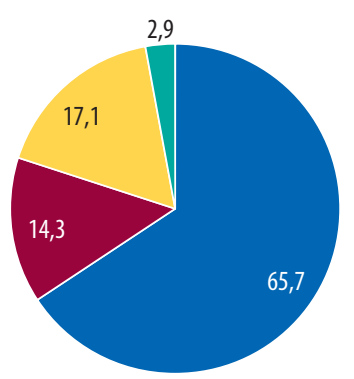

- Переддементні когнітивні порушення - Деменція легкого ступеня вираженості Немає порушень когнітивних функцій — Деменція помірного ступеня вираженості

Когнітивні порушення при фібриляції передсердь проявляються у вигляді субклінічних, тобто «німих» інсультів. Мікроінфаркти можуть бути пов'язані з артеріолосклерозом, атеросклерозом крупних мозкових артерій.

Важливим фактором ризику розвитку когнітивних порушень $\epsilon$ цукровий діабет. Головний мозок - безпосередній учасник регуляції рівня глюкози у крові. До того ж саме глюкоза $\epsilon$ тим фактором, який призводить до розвитку когнітивних порушень. Основні механізми ураження головного мозку при цукровому діабеті пов'язані з розвитком мікро-і макроангіопатії, центральної діабетичної полінейропатії. Наразі навіть сформувалася концепція - «діабетичний мозок», що у деяких публікаціях називають цукровим діабетом 3-го типу. Дослідження у різних етнічних групах показали, що цукровий діабет 2-го типу корелює з помірним когнітивним зниженням і ризиком розвитку хвороби Альцгеймера: виявлено підвищення ризику її розвитку у 1,8 раза та судинної деменції у 2,3 раза [18, 19]. Парадигма «діабетичного мозку» полягає у повільному формуванні, початковому перебігу без явних неврологічних і нейропсихологічних проявів. На перших етапах розвитку за- хворювання з'являються астенічні, емоційні симптоми 3 наступним когнітивним порушенням [20]. Структурні зміни головного мозку при цукровому діабеті представлені на рис. 5.

Рисунок 5 Структурні зміни головного мозкупри цукровомудіабеті [21]

\begin{tabular}{|c|c|c|c|}
\hline \multirow{2}{*}{$\begin{array}{c}\text { Здоровий } \\
\text { мозок }\end{array}$} & $\begin{array}{l}\text { Ураження } \\
\text { гіпокампа }\end{array}$ & $\begin{array}{l}\text { ктури } \\
\text { ни }\end{array}$ & \multirow{2}{*}{$\begin{array}{l}\text { Нейрокогнітивнд } \\
\text { дисфункція }\end{array}$} \\
\hline & $\begin{array}{l}\text { Зниження щільності } \\
\text { сірої речовини }\end{array}$ & Атрофія & \\
\hline
\end{tabular}

Початок Похилий цукрового діабету вік

Пов'язані з цукровим діабетом ризики нейрокогнітивної дисфункції

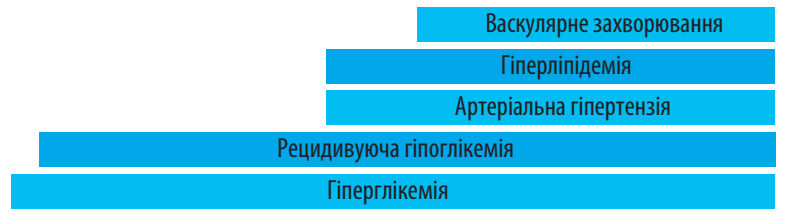

Встановлено, що наявність факторів кардіоваскулярного ризику у середньому віці $\epsilon$ потужним предиктором розвитку деменції протягом наступних 10 років [22]. 3 практичної точки зору, це означає, що у пацієнта з високим серцево-судинним ризиком підвищений ризик розвитку не тільки кардіоваскулярних катастроф, але й у подальшому - деменції [23].

Останнім часом багаточисленні морфологічні зіставлення свідчать про високу коморбідність цереброваскулярних і нейродегенеративних захворювань, зокрема хвороби Альцгеймера. Наразі сформувалася концепція змішаної деменції: виявлено взаємний вплив судинного і нейродегенеративного процесу на патогенетичному рівні. Хронічна ішемія і гіпоксія головного мозку $\epsilon$ факторами ризику розвитку церебрального амілоїдозу — головної патогенетичної події хвороби Альцгеймера. Таким чином, хронічна недостатність мозкового кровообігу зумовлює схильність до розвитку нейродегенеративного процесу. Крім того, інфаркти головного мозку сприяють більш швидкій клінічній маніфестації асимптомного або малосимптомного нейродегенеративного процесу.

Все це супроводжується змінами на молекулярному і клітинному рівні. Механізми формування когнітивних порушень включають оксидативний стрес, запалення, ендотеліальну дисфункцію, порушення трансмембранних білків з утворенням $\beta$-амілоїду і формуванням амілоїдних бляшок. Все це призводить до порушення нейропластичності і розвитку нейродегенеративного процесу.

Нейрорадіологічний профіль структурних змін речовини головного мозку при церебральній мікроангіопатії характеризується наявністю лакунарних інфарктів (підкоркові ганглії, внутрішня капсула, глибока біла речовина півкуль), мікрокрововиливів, розширенням субарахноїдальних просторів, лейкоареозом. Це досить типова картина, яка дозволяє верифікувати саме судинну патологію. Проте при хворобі Альцгеймера спостерігається атрофія інших структур - медіальних відділів скроневої частки (гіпокампа і мигдалини). Суттєвим маркером $\epsilon$ відкладення $\beta$-амілоїду в головному мозку, який верифікується за даними позитронно-емісійної томографії.

У когнітивній сфері ураження підкоркових структур із вторинною лобовою дисфункцією проявлятиметься наступними клінічними ознаками:

- брадифренія (сповільненість темпу когнітивних процесів), труднощі у концентрації уваги, відволікання, підвищена втомлюваність при розумовій роботі);

- труднощі з перемиканням уваги і зміною парадигми діяльності, інертність, акайрія, персеверація;

- недостатність когнітивного контролю, імпульсивність при прийнятті рішень, зниження критики, безтактність, асоціальна поведінка (зазвичай при значній вираженості когнітивних порушень в цілому); 
- порушення пам'яті за типом недостатності відтворення (труднощі з витягуванням із пам'яті у потрібний момент необхідної інформації; полегшити процес відтворення можуть підказки або надання множинного вибору);

- зорово-просторові розлади (зазвичай при значній вираженості когнітивних порушень в цілому): конструктивна диспраксія, просторова дисгнозія.

При цьому про супутню хворобу Альцгеймера свідчать більш виражені порушення пам'яті, прогресуючий характер мнестичних розладів, виражене більшою мірою порушення пам'яті на нещодавні події порівняно 3 віддаленими (закон Рібо), специфічні особливості мнестичних розладів, що свідчать про первинну недостатність запам'ятовування (не відтворення):

- значна різниця безпосереднього і відстроченого відтворення, порушення впізнавання у спробах з множинним вибором, неефективність підказок при відтворенні, додавання стороннього матеріалу при відтворенні (пацієнт намагається вгадати правильну відповідь);

недостатність номінативної функції мови (порушено називання предметів) у відсутності післяінсультної афазії.

\section{Як же зробити життя пацієнтів повноцінним?}

Особливо важливі рання діагностика і ранній початок лікування, оскільки деякі порушення когнітивних функцій можуть бути зворотними, а можливості терапії у розгорнутій стадії когнітивних розладів вельми обмежені. Уточнення клінічних особливостей захворювання, його якісних і кількісних характеристик допомагають у топічній і нозологічній діагностиці. Темпи прогресування когнітивних розладів $\epsilon$ важливим елементом контролю ефективності лікувальних заходів і вибору терапевтичної тактики.

Корекція і профілактика прогресування когнітивних порушень включають корекцію факторів ризику, вплив на нейротрансмітерні системи, цитопротекцію і нейрорепарацію. Когнітивна недостатність - багатофакторна патологія, що обумовлена дією різних патофізіологічних механізмів, і потребує застосування препаратів із мультимодальною дією. Серед таких препаратів - оригінальний високостандартизований екстракт гінкго білоба (EGb 761®, виробник «Dr. Willmar Schwabe $\mathrm{GmbH} \&$ Co. KG», Німеччина), який характеризується високим рівнем доведеної ефективності при когнітивних порушеннях, за результатами системних оглядів і метааналізів (Канада 7 досліджень, 2625 пацієнтів; Швейцарія - 4 дослідження, 1628 пацієнтів; Китай - 9 досліджень, 2561 пацієнт; Японія 13 досліджень, 2381 пацієнт) [24-27].

В Україні зареєстровані препарати оригінального EGb $761^{\circledR}$ від «Dr. Willmar Schwabe GmbH \& Co. KG» у різних дозуваннях: Мемоплант (40 мг в 1 табл.), Мемоплант форте (80 мг в 1 табл.) та Тебокан (120 мг в 1 табл.), ексклюзивним постачальником $\epsilon$ компанія «Альпен Фарма АГ». Механізм дії оригінального високостандартизованого екстракту гінкго білоба (EGb 761®) представлений в табл. 4.

Таблиця 4 Механізм дії оригінального стандартизованого екстракту гінкго білоба $\left(\mathrm{EGb} 761^{\circledR}\right)$

\begin{tabular}{|c|c|c|}
\hline $\begin{array}{l}\text { Нейропротекторна } \\
\text { активність }\end{array}$ & $\begin{array}{c}\text { Вплив на баланс } \\
\text { нейротрансмітерів }\end{array}$ & $\begin{array}{l}\text { Покращення } \\
\text { кровообігу }\end{array}$ \\
\hline Антигіпоксичні ефекти & $\begin{array}{l}\text { Покращення навчання і } \\
\text { пам'яті }\end{array}$ & $\begin{array}{l}\text { Підвищення мозкового } \\
\text { кровотоку }\end{array}$ \\
\hline Радикальне очищення & $\begin{array}{l}\text { Зменшення вираженості } \\
\text { симптомів, викликаних стресом }\end{array}$ & $\begin{array}{l}\text { Модулювання проникності } \\
\text { судин }\end{array}$ \\
\hline $\begin{array}{l}\text { Збільшення кількості } \\
\text { антиоксидантних ферментів }\end{array}$ & $\begin{array}{l}\text { Незначна антидепресантна й } \\
\text { анксіолітична активність }\end{array}$ & $\begin{array}{l}\text { Попередження дисфункції } \\
\text { ендотелію }\end{array}$ \\
\hline $\begin{array}{l}\text { Покращення функції мітохон- } \\
\text { дрій }\end{array}$ & $\begin{array}{l}\text { Підвищення концентрації до- } \\
\text { фаміну в корі головного } \\
\text { мозку }\end{array}$ & \\
\hline Покращення кліренсу білка & $\begin{array}{l}\text { Підвищення довгостроково- } \\
\text { го потенціювання }\end{array}$ & \\
\hline
\end{tabular}

В ході фармакологічних досліджень було доведено, що стандартизований екстракт гінкго білоба (EGb 761) підвищує переносимість гіпоксії, особливо в тканинах головного мозку; інгібує розвиток і прискорює регресію набряку мозку, спричиненого травмою або отруєнням; зменшує набряк сітківки ока і ушкодження рогівки; інгібує пов'язане з віком зменшення мускаринових холінергічних рецепторів і $a_{2}$-адренергічних рецепторів, а також збільшення споживання холіну в гіпокампі; покращує пам'ять i здатність до навчання; поліпшує компенсацію порушень рівноваги; збільшує кровотік, особливо в ділянці мікроциркуляції; покращує реологічні характеристики крові; інактивує токсичні кисневі радикали; виявляє антагонізм до чинника активації тромбоцитів $\mathrm{i}$ чинить нейрозахисну дію.

$\mathrm{EGb} 761^{\circledR}$ включений у міжнародні протоколи з лікування деменції протягом багатьох років, що свідчить про те, що постійно розширюються діагностичні можливості щодо когнітивних порушень і $\epsilon$ підвищений інтерес до цієї проблеми і призначення даного препарату хворим із когнітивними порушеннями [28-31]. Екстракт гінкго білоба також включений до Українського Уніфікованого клінічного протоколу первинної, вторинної (спеціалізованої), третинної (високоспеціалізованої) та паліативної медичної допомоги «Деменція» [32]. У рекомендаціях Всесвітньої федерації товариств з психіатрії (World Federation of Societies of Biological Psychiatry - WFSBP) з лікування хвороби Альцгеймера і різних видів деменції в переліку з п'яти рекомендованих препаратів зазначено оригінальний високостандартизований екстракт гінкго білоба (EGb 761) в дозі 240 мг на добу, як у монотерапії, так і в комбінації з іншими препаратами для корекції НКР різного ступеню (малих та великих НKP). EGb $761^{\circledR}$ продемонстрував зіставний рівень доказовості із синтетичними препаратами (інгібіторами холінестерази та мемантином) та кращий профіль безпеки. При застосуванні EGb $761^{\oplus}$ відмічено покращення когнітивних функцій, поведінки й активності у повсякденному житті при хворобі Альцгеймера і судинній деменції [28].

\section{Список використаної літератури}

1. Vos Th., Flaxman A.D., Naghavi M. et al. (2012) Years lived with disability (YLDs) for 1160 sequelae of 289 diseases and injuries 1990-2010: a systematic analysis for the Global Burden of Disease Study 2010. Lancet, 380(9859): 2163-2196. doi: 10.1016/50140-6736(12)61729-2.

2. https://dsm.psychiatryonline.org/doi/book/10.1176/appi.books. 9780890425596

3. Launer L.J., Andersen K., Dewey M.E. et al. (1999) Rates and risk factors for dementia and Alzheimer's disease: results from EURODEM pooled analyses. EURODEM Incidence Research Group and Work Groups. European Studies of Dementia. Neurology, 52(1): 78-84. doi: 10.1212/wnl.52.1.78.

4. Kramer A.F., Bherer L., Colcombe S.J. et al. (2004) Environmental influences on cognitive and brain plasticity during aging. J. Gerontol. A Biol. Sci. Med. Sci., 59(9): M940-M957. doi: 10.1093/gerona/59.9.m940.

5. Lin F.R. (2011) Hearing Loss and Cognition Among Older Adults in the United States. J. Gerontol. A Biol. Sci. Med. Sci., 66A(10): 1131-1136. doi: 10.1093/gerona/glr115.

6. Gates G.A. (2012) Central presbycusis: an emerging view. Otolaryngol. Head Neck Surg., 147(1): 1-2. doi: 10.1177/0194599812446282.

7. Valentijn S.A.M., van Boxtel M.P.J., van Hooren S.A.H. et al. (2005) Change in sensory functioning predicts change in cognitive functioning: results from a 6-year follow-up in the maastricht aging study. J. Am. Geriatr. Soc., 53(3): 374-380. doi: 10.1111/j.1532-5415.2005.53152.x.

8. Anstey K.J., Hofer S.M., Luszzz M.A. (2003) A latent growth curve analysis of late-life sensory and cognitive function over 8 years: evidence for specific and common factors underlying change. Psychol. Aging, 18(4): 714-726. doi: 10.1037/0882-7974.18.4.714.

9. Mirza S.S., Wolters F.J., Swanson S.A. et al. (2016) 10-year trajectories of depressive symptoms and risk of dementia: a population-based study. Lancet Psychiatry, 3(7): 628-635. doi: 10.1016/S2215-0366(16)00097-3.

10. American Academy of Neurology (AAN) (2021) 2021 Annual Meeting: Presentation 003, Apr. 20.

11. de Gage S.B., Moride Y., Ducruet Th., Kurth T. (2014) P.5.a.003 Increased risk of Alzheimer's disease in benzodiazepine long-term users: a case — control study. Eur. Neuropsychopharmacol., 24: S626. D0I:10.1016/S0924-977X(14)71005-3.

12. Tapiainen V., Taipale H., Tanskanen A. et al. (2018) The risk of Alzheimer's disease associated with benzodiazepines and related drugs: a nested case — control study. Acta Psychiatr. Scand., 138(2): 91-100. doi: 10.1111/acps. 12909. 
13. Centers for Medicare \& Medicaid Services (2014) Chronic Conditions Overview (https://www.cms. gov/Research-Statistics-Data-and-Systems/Statistics-Trends-and-Reports/Chronic-Conditions).

14. Wolters F.J., Zonneveld H.I., Hofman A. et al. (2017) Cerebral Perfusion and the Risk of Dementia: A Population-Based Study. Circulation, 136(8): 719-728. doi: 10.1161/CIRCULATIONAHA.117.027448.

15. Bell R.D., Winkler E.A., Sagare A.P. et al. (2010) Pericytes control key neurovascular functions and neuronal phenotype in the adult brain and during brain aging. Neuron, 68(3): 409-427. doi: 10.1016/j.neuron.2010.09.043.

16. Montagne A., Nikolakopoulou A.M., Zhao Zh. et al. (2018) Pericyte degeneration causes white matter dysfunction in the mouse central nervous system (https://www.nature.com/articles/ nm.4482).

17. Zarudskiy A.A., Vorobieva A.S., Yashchenko E.A. et al. (2018) Progression of cognitive impairment in patients with systolic chronic heart failure (https://science-education.ru/ru/ article/view?id=27682). (In Rus.).

18. Gelber R.P., Launer L.J., White L.R. (2012) The Honolulu-Asia Aging Study: epidemiologic and neuropathologic research on cognitive impairment. Curr. Alzheimer Res., 9(6): 664-672. doi: 10.2174/156720512801322618.

19. Jacobson A.M., Braffett B.H., Cleary P.A. et al. (2013) The long-term effects of type 1 diabetes treatment and complications on health-related quality of life: a 23-year follow-up of the Diabetes Control and Complications/Epidemiology of Diabetes Interventions and Com-plications cohort. Diabetes Care, 36(10): 3131-3138. doi: 10.2337/dc12-2109.

20. Soares E., Nunes S., Reis F., Pereira F.C. (2012) Diabetic encephalopathy: the role of oxidative stress and inflammation in type 2 diabetes. Int. J. Interferon Cytokine Mediator Res., 4: 75-85. https://doi.org/10.2147/IJICMR.S29322.

21. Seaquist E.R. (2010) The final frontier: how does diabetes affect the brain? Diabetes, 59(1): 4-5. doi: 10.2337/db09-1600.

22. Kaffashian S., Dugravot A., Elbaz A. et al. (2013) Predicting cognitive decline: a dementia risk score vs. the Framingham vascular risk scores. Neurology, 80(14): 1300-1306. doi: 10.1212/ WNL.0b013e31828ab370.
23. Diener H.C. (2018) Preventing dementia beyond treating hypertension. Eur. Heart J., 39(33): 3126-3127. doi: 10.1093/eurheartj/ehy409.

24. Gauthier S., Schlaefke S. (2014) Efficacy and tolerability of Ginkgo biloba extract EGb $761^{\oplus}$ in dementia: a systematic review and meta-analysis of randomized placebo-controlled trials. Clin. Interv. Aging, 9: 2065-2077. doi: 10.2147//IA.S72728.

25. Savaskan E., Mueller H., Hoerr R. et al. (2018) Treatment effects of Ginkgo biloba extract EGb $761^{\oplus}$ on the spectrum of behavioral and psychological symptoms of dementia: meta-analysis of randomized controlled trials. Int. Psychogeriatr., 30(3):285-293. doi: 10.1017/S1041610217001892.

26. Tan M.-Sh., Yu J.-T., Tan Ch.-Ch. et al. (2015) Efficacy and adverse effects of ginkgo biloba for cognitive impairment and dementia: a systematic review and meta-analysis. J. Alzheimers Dis., 43(2): 589-603. doi: 10.3233/JAD-140837.

27. Hashiguchi M., Ohta Y., Shimizu M. et al. (2015) Meta-analysis of the efficacy and safety of Ginkgo biloba extract for the treatment of dementia. J. Pharm. Health Care Sci., 1: 14. doi: 10.1186/s40780-015-0014-7.

28. Ihl R., Frölich L., Winblad B., Schneider L. (2011) WFSBP Task Force on Treatment Guidelines for Alzheimer's Disease and other Dementias. World Federation of Societies of Biological Psychiatry (WFSBP) guidelines for the biological treatment of Alzheimer's disease and other dementias. World Federation of Societies of Biological Psychiatry (WFSBP). World J. Biol. Psychiatr., 12(1): 2-32. D01:10.3109/15622975.2010.538083.

29. Tible 0.P., Riese F., Savaskan E., von Gunten A. (2017) Best practice in the management of behavioural and psychological symptoms of dementia. Ther. Adv. Neurol. Disord., 10(8): 297-309. doi: 10.1177/1756285617712979.

30. http://www.dgn.org/leitlinien/3176-leitlinie-diagnose-und-therapie-von-demenzen-2016

31. Luzny J., Holmerova I., Wija P., Ondrejka I. (2014) Dementia Still Diagnosed Too Late — Data from the Czech Republic. Iran J. Public Health, 43(10): 1436-1443.

32. Ministry of Health of Ukraine (2016) Order of the Ministry of Health of Ukraine dated 19.07.2016 № 736 «On approval and implementation of medical and technological documents for standardization of medical care for dementia» (https://dec.gov.ua/wp-content/ uploads/2019/11/2016_736_ykpmd_dem.pdf). (In Ukr.).

\section{Відомості про автора:}

Дзяк Людмила Антонівна — доктор медичних наук, професор, член-кореспондент НАМН України, заслужений діяч науки і техніки України, лауреат Державної премії України, завідувач кафедри нервових хвороб та нейрохірургії факультету післядипломної освіти державного закладу «Дніпровський державний медичний університет», Дніпро, Україна.

Адреса для кореспонденції:

Дзяк Людмила Антонівна

49044, Дніпро, вул. Вернадського, 9

\section{Information about the author:}

Dzyak Lyudmyla A. — Doctor of Medical Sciences, Professor, Corresponding Member of the National Academy of Medical Sciences of Ukraine, Honored Worker of Science and Technology of Ukraine, Laureate of the State Prize of Ukraine, Head of the Department of Nervous Diseases and Neurosurgery, Dnipro State Medical University, Dnipro, Ukraine.

\section{Address for correspondence:}

Lyudmyla Dzyak

49044, Dnipro, Vernadsky str., 9 
ТЕСТОВІ ЗАПИТАННЯ

(один або декілька правильних варіантів відповідей на кожне запитання)

1. При яких захворюваннях можливий розвиток когнітивної недостатності?

$\square$ тільки неврологічних

$\square$ при самих різних, не тільки неврологічних (при різних токсичних ураженнях, багатьох соматичних захворюваннях тощо)

2. На фоні яких захворювань можуть розвиватися нейрокогнітивні порушення?

$\square$ первинні нейродегенеративні захворювання

$\square$ нейроінфекції

$\square$ демієлінізуючі захворювання нервової системи

$\square$ серцево-судинні захворювання

$\square$ захворювання головного мозку

$\square$ дисметаболічні розлади

$\square$ черепно-мозкова травма

$\square$ пухлини головного мозку

$\square$ розлади ліквородинаміки

$\square$ все вищезазначене

3. Діагностичні критерії великого НКР:

$\square$ наявність вираженого когнітивного зниження порівняно з вихідним рівнем в $\geq 1$ домені когнітивних функцій (пацієнт, обізнані близькі або лікуючий лікар відзначають істотне зниження когнітивних функцій та виявляють виражені порушення когнітивних функцій, переважно підтверджені при стандартизованому нейропсихологічному тестуванні або в процесі іншої кількісної клінічної оцінки)

$\square$ наявність помірного когнітивного зниження порівняно з вихідним рівнем в $\geq 1$ домені когнітивних функцій (па- цієнт, обізнані близькі або лікуючий лікар відзначають легке зниження когнітивних функцій та виявляють помірні порушення когнітивних функцій, переважно підтверджені при стандартизованому нейропсихологічному тестуванні або в процесі іншої кількісної клінічної оцінки)

$\square$ когнітивний дефіцит знижує незалежність у побуті

$\square$ когнітивний дефіцит не знижує незалежності у побуті

4. Основний фактор ризику розвитку деменції:

$\square$ дисметаболічні розлади

$\square$ черепно-мозкова травма

$\square$ вік

$\square$ пухлини головного мозку

$\square$ обтяжена спадковість

口 шкідливі звички

5. Деменція:

$\square \in$ нормальним процесом старіння

$\square$ не $\epsilon$ нормальним процесом старіння

6. Найпоширеніший симптом хвороби Альцгеймера:

$\square$ погіршення пам'яті

$\square$ проблеми з мовою

$\square$ часті зміни настрою, депресія, апатія

7. Механізм дії стандартизованого екстракту гінкго білоба:

$\square$ нейропротекторна активність

$\square$ вплив на баланс нейротрансмітерів

$\square$ покращення кровообігу

$\square$ все вищезазначене

\section{Для отримання сертифіката дайте відповідь на тестові запитання в режимі on-line на сайті журналу www.umj.com.ua або надішліть ксерокопію сторінок з відповідями разом з контактною інформацією за адресою: 01001, Київ-1, a/c «В»-82, ТОВ «МОРІОН»}

ПІБ

Поштова адреса: індекс
область
район
місто
вулиця
будинок
квартира
Телефон
E-mail

